\title{
Pro-contradiscussie over medisch onderwijs*
}

\author{
J.C.C. Borleffs
}

Sinds het einde van de vorige eeuw ondergaat het medisch onderwijs grote veranderingen. Dit geldt niet alleen voor Nederland. Ook buiten onze landsgrenzen woedt de geest van vernieuwing in zowel de initiële opleiding als de medisch-specialistische vervolgopleidingen. ${ }^{1}$ In Nederland hebben de acht medische faculteiten en academische ziekenhuizen (universitair-medische centra, UMC's) de aanzet voor de verandering gegeven, maar ook binnen de niet-academische ziekenhuizen zijn veel initiatieven tot vernieuwing genomen.

In meerdere opzichten vormen die veranderingen een breuk met het verleden. Ofschoon alle faculteiten hun eigen signatuur hebben behouden, zijn er gezamenlijke kenmerken, zoals integratie van kliniek en prekliniek, thematisch in plaats van disciplinegebonden aanbieden van de stof, grote aandacht voor de ontwikkeling van professioneel gedrag, contextgerelateerd leren, kleinschalig onderwijs en eigen verantwoordelijkheid van de student voor het leerproces. Voorts is in enkele curricula het zesde jaar geprogrammeerd als schakel naar de vervolgopleiding.

Bij de medisch-specialistische vervolgopleidingen volgde de start van het veranderingsproces een aantal jaren later. Het Centraal College Medische Specialismen (CCMS) legde eind 2004 in een kaderbesluit vast dat de wetenschappelijke verenigingen voorstellen voor modernisering van de medisch-specialistische opleidin- gen moeten doen. ${ }^{2}$ Aanvankelijk moest dat vóór 1 januari 2005 gebeurd zijn, maar inmiddels hebben de verenigingen daarvoor tot medio 2007 de tijd gekregen. Een belangrijke reden van de modernisering is dat de omstandigheden waarin de opleidingen plaatsvinden sterk veranderd zijn, zoals de veranderde aantallen arts in opleiding tot specialist (aios), de toegenomen 'productie'-druk in de patiëntenzorg, de druk op de opleidingsduur en de noodzaak om deeltijdopleidingen aan te bieden. Voorts stelt het CCMS dat algemene competenties van de specialist versterkt dienen te worden en dat, in navolging van de artsopleiding, bij de specialisatie nieuwe onderwijskundige mogelijkheden en ontwikkelingen moeten worden benut. De bedoeling van deze modernisering van de opleidingen is om de kwaliteit en de doelmatigheid ervan te vergroten. Met dit kaderbesluit sluit het CCMS aan op adviezen in het rapport van de Projectgroep Medisch Opleidingscontinuüm De arts van straks, ${ }^{3}$ en dat van de Commissie Implementatie Opleidingscontinuüm en Taakherschikking De zorg van morgen. ${ }^{4}$

Parallel aan deze ontwikkelingen binnen de beroepsgroep wordt ook op overheidsniveau gewerkt aan de modernisering. De minister van Volksgezondheid, Welzijn en Sport heeft hiervoor de opdracht gegeven aan de Stuurgroep Modernisering van de Opleidingen en Beroepsuitoefening in de Gezondheidszorg. Deze stuurgroep heeft als taak om in nauw overleg met het veld

* Dit artikel verschijnt ook in het Nederlands Tijdschrift voor Geneeskunde. 
binnen 5 jaar een samenhangend stelsel van eindtermen van de initiële en de vervolgopleidingen op te zetten.

In alle initiatieven staat de noodzaak centraal om te komen tot een grotere doelmatigheid van de medische opleidingen. Een van de aspecten van die grotere doelmatigheid betreft een efficiëntere aansluiting van de initiële opleiding op de medisch-specialistische vervolgopleidingen. Het gevolg hiervan kan zijn dat het totale opleidingstraject, van eerstejaarsstudent tot medisch specialist, korter wordt, dan wel dat de opleidingstijd efficiënter wordt besteed.

Deze veranderingen gaan niet zonder slag of stoot. Zowel voor de student en de aios als voor de docent en de clinicus heeft deze modernisering grote gevolgen. De modernisering roept dan ook vele vragen op. Leiden wij hierdoor betere dokters op? Zijn zij beter toegerust voor hun taken dan de artsen die opgeleid zijn in oude programma's? Moeten oude, vaak traditionele standpunten over wat goed onderwijs is, worden herzien omdat nieuwe onderwijskundige concepten laten zien dat het ook anders en wellicht beter kan? Wat is de goede balans tussen patiëntenzorg, onderwijs en onderzoek? Hoe kan de professionalisering van de docent op een efficiënte manier plaatsvinden? Wat is de taakverdeling tussen UMC's en niet-academische ziekenhuizen bij de opleiding? Dit zijn slechts enkele voorbeelden van de vele vragen die op dit moment leven bij iedere medicus die een rol vervult in het onderwijs.
Om bij te dragen aan de discussie over deze vragen starten het Nederlands Tijdschrift voor Geneeskunde en het Tijdschrift voor Medisch Onderwijs gezamenlijk een rubriek 'pro-contra'. Na een inventarisatie van interessante thema's en vragen zijn voor ieder onderwerp een pro- en een contrastelling geformuleerd. Vervolgens is voor elke stelling een auteur uitgenodigd om deze zo goed mogelijk onderbouwd te verdedigen. De bijdragen zullen tegelijkertijd in beide tijdschriften worden gepubliceerd.

\section{Literatuur}

1. Anderson MB, editor. A snapshot of medical students' education at the beginning of the 21 st century: reports from 130 schools. Acad Med 2000;75: S1-S460.

2. Bleker OP, Hoorntje JCA, Schelfhout VJ. Beter en leuker, CCMS ontvouwt plannen voor de vervolgopleiding van medisch specialisten. Med Contact 2004;59:1692-5.

3. Meyboom-de Jong B, Schmit Jongbloed LJ, Willemsen MC, editors. De arts van straks, een nieuw medisch opleidingscontinuüm. Utrecht: KNMG/ DMW-VSNU/VAZ/NVZ/LCVV; 2002.

4. LeGrand-van den Bogaard MJM, Rooijen APN, editors. De zorg van morgen, flexibiliteit en samenhang. Rapport van de Commissie Implementatie Opleidingscontinuüm en Taakherschikking. Den Haag: Ministerie van VWS; 2003.

\section{De auteur:}

Prof. dr. J.C.C. Borleffs is hoofdredacteur van het Tijdschrift voor Medisch Onderwijs.

\section{Correspondentieadres:}

Prof. dr. J.C.C. Borleffs, UMC Utrecht, directie Onderwijs en Opleidingen, Postbus 85500, 3506 GA Utrecht, j.c.c.borleffs@umcutrecht.nl.

\section{Summary}

Since the end of the last century, medical education is being renewed in many countries. There is a tendency toward integration of clinical and pre-clinical knowledge, presentation of basic science topics as themes of organ systems in conjunction with clinical cases, emphasis on professional attitude, context-related and small-scale learning and the own responsibility of the student. As a contribution to the discussion, the Nederlands Tijdschrift voor Geneeskunde (Dutch Journal of Medicine) and Tijdschrift voor Medisch Onderwijs (Dutch Journal of Medical Education) have decided to publish articles in a pro and contra format. (Borleffs JCC. Pro and contra discussion about medical education. Dutch Journal of Medical Education 2006;25(1):39-40.) 